\title{
Teachers Management and Control of Information and Communication Technology (ICT) Facilities for Effective Teaching and Learning in J unior Secondary Schools
}

\author{
I ke Eucharia Ada
}

\author{
Department of Agricultural and Home Economics Education \\ Michael Okpara University of Agriculture ,Umudike -Umuahia Abia State,Nigeria
}

\section{Doi:10.5901/ ajis.2013.v2n10p99}

\begin{abstract}
Information and communication Technology (ICT) in the 21st century, has become a globalize issue in the education sector, on the improvement and actualization of standard in instructional process in the Junior Secondary Schools. ICT is replacing the face to face teaching and learning system in Nigeria Education system, so as to meet up with the demands of the global learning system. This paper therefore examined teachers' management and control of learning at the Junior Secondary Schools in Umuahia North of Abia-State Nigeria. Four research questions were formulated to guide the study. A modified four point Licket scale questionnaire was structured by the researcher for data collection. The results of the scores were analyzed using the mean rating of 2.50 as the cut of point for all levels of decisions. The population for the study consisted of 15 JSS and 608 JSS teachers. A simple random sampling technique was adopted for the sampling of the respondents. Analysis of data was conducted and results of findings analyzed. Discussions of findings were made. Conclusions were drawn, and recommendations made on the ways forward, for effective management and control of ICT facilities to enhance teaching and learning in schools.
\end{abstract}

\section{I ntroduction}

Education is the main process through which society or the nation regenerate itself and hand down not just culture, but also its discoveries and inventions, institutional memory and its entire wealth of expertise to younger generations. Education is therefore the soul of society and if we remove education, the society decays and withers away using the words of Karl Marx (1848). The teacher is an important determinant of the pace of progress of any educational system. He is like a diver who is driving a vehicle to a destination. No input is more critical in the education system than the teacher. His action can either make or destroy the system. His job is very powerful, that it can be said to be the reproduction of the society. No society can grow more than the teacher.

According to the National Policy on Education (2008) stated that "no educational system can rise above the quality of the teachers." Also the school is an insignificant part of the society. It cannot operate in isolation of the society, it must be part of it, by reflecting the culture, norms, values and aspirations of the society. In the consideration of the importance of the teacher in the reproduction of the society, it is therefore very expedient to get such teachers well equipped for the reproduction of the society.

But the problem is that most of these teachers are not conversant with the use of ICTs for teaching in the classrooms. They cannot actually turn on the Lap/desk top, computers, let alone use it as managers of the classrooms, to teach, as it is a globalize instructional process, for effective leaning.

More so, they lack the interest, competence and ICT facilities tat can aid instructional process. To fill this gap, solutions are sought through a rigorous systematic process, to finding a lasting 
solution to them.

The information age is not just affecting the workplace; its influences are felt in our educational system too. New and emerging technology challenges the traditional instructional process and the way education is managed. It is vital that the teachers in the JSS keep pace with the challenges of modern teaching strategies that are used in delivering concepts to the learners. Problems of ICT facilities, which come to ones mind include, difficulty of access, exorbitant cost, irregularity of access, above all there is unqualified and lack of manpower. Ali (2002) reported that about $90.2 \%$ of Nigerians have no satellite-based remote sensing, telescope or Global system Mobile (GSM) networking, no computer network system in offices and at schools, even the ones we have are of substandard as the standard ones are expensive to comeby. School administrators should therefore ensure the availability and utilization of the ICT facilities. Research have identified that Nigeria is much backward in the use of ICT in education (Obagah 2003). Only a few schools have ICT facilities and they are in the private schools, the public schools have nothing to show. ICT facilities can contribute to the attainment of our educational goals, but if not dictated and used, properly, can frustrate the goals. Hence the focus for this paper.

The purposes for the study of this work therefore are to:

1. Investigate teachers management and control of ICT facilities for effective teaching and learning in the classroom in JSS in Umuahia north L.G.A. of Abia State.

2. Investigate that teachers are computer literate but lack ICT facilities for instruction.

3. examine whether with availability of ICT, teachers have interest to use ICT in the schools.

4. Find out school administrators implication for the use of ICT facilities in schools.

The significance of this paper will, enable all the teachers to have the knowledge, competencies interests and skills to operate the ICT facilities for instructional process. Information and communication Technology (ICT) has great potential applications in all aspects of life, especially in science. Its potentials and applications lie in the use to collect, process, store, edit, retrieve and pass information in various forms. Being the most current technology application to different fields of human endevour, education inclusive, several studies have been conducted and used to move the nation forward through science education (Ezeliora 2003 and Okwo 2002). The use and application of ICT facilities in secondary schools is desirable, consecrating its relevance to technological advancement and national development. The Junior Secondary Schools J SS precisely, will also benefit. They will act as tools for solving the problems of health, over population, agriculture and others. ICT will substantially change the world, create new patterns of social and economic interactions and transforming life styles, work and communication. ICT will help learner become familiar with the use of ICT facilities since all jobs in the society and in future depend on it and also to use it in teaching to enhance instructional process (Smith 2002)

\section{Research Questions}

The following research questions were formulated to guide the study.

1. To what extent are ICT facilities available in the schools for teaching?

2. To what extent do the teachers in the school use available ICT facilities, for teaching and learning?

3. What are the problems faced with the use of available ICT facilities for teaching and learning?

4. What are the implications for the administrators in the availability and utilization of ICT in the schools?

\section{Method}

The study was carried out using a descriptive survey design method.

The population for the study consisted of the 608 J SS teachers from the 15 J unior Secondary 
Schools (JSS). While 102 teachers were sampled. Out of the 608 JSS teachers in the L.G.A., 102 JSS teachers were randomly sampled adopting a ballot picking technique, so, a total of 102 teachers formed the subjects for the study. The questionnaire, which was used, was developed by the researcher, for the data collection. The questionnaire consisted of four sections. Section I, sought for the availability of ICT facilities using 4 point response scale of Very High Extent $=4$, High Extent $=3$, Low Extent $=2$, No Extent $=1$ section II focused on the extent of the use of ICT facilities, using 4 point response scale of Very High Extent $=4$ High extent $=3$, Low Extent $=2$ and No Extent $=1$. Section III was based on the factors that hinder effective use of ICT facilities, using 4 point response scale of strongly Agree $=4$, Agree $=3$, Disagree $=2$, Strongly Disagree $=1$. Section IV focused on implication for administrators in the availability and utilization of ICT facilities in schools using 4 point response scale of Strongly Agree $=4$ Agree $=3$, Disagree $=2$ and Strongly Disagree $=1$. The questionnaires were validated by two lecturers from the department. A total of 102 copies of the questionnaires were distributed to the 102 respondents who formed the sample for the study. All the distributed copies were duly completed, retrieved and analyzed. The data were analyzed using mean scores. A mean rating of 2.50 was accepted as cut off point for different levels of responses.

\section{Results}

Following analysis of data collection, results are presented in line with the research questions.

Table 1: The extent of ICT facilities available for teaching in schools

\begin{tabular}{|c|l|c|c|c|c|c|c|}
\hline S/N & \multicolumn{1}{|c|}{ Items } & VHE & HE & LN & NE & X & Decision \\
\hline 1 & Computer & 8 & 14 & 20 & 62 & 1.7 & No Extent \\
\hline 2 & Computer software programme & 10 & 4 & 18 & 70 & 1.5 & No Extent \\
\hline 3 & Television sets and video cassettes & 0 & 4 & 6 & 94 & 1.23 & No Extent \\
\hline 4 & Internet & 6 & 2 & 14 & 82 & 1.4 & No Extent \\
\hline 5 & transparencies & 2 & 6 & 8 & 88 & & No Extent \\
\hline 6 & Over head and slide projects & 4 & 10 & 8 & 82 & 1.4 & No Extent \\
\hline
\end{tabular}

Table I, showed that all the items on this table, have the mean scores of $1.7,1.5,1.23,1.4,1.3$, and 1.4 respectively indicating that, none of the schools in the Umuahia North have ICT facilities for teaching. They are all below 2.50 mean values which is the cut off point, indicating that the schools to no extent, use ICT facilities for their instructional process.

Table 2: The extent of use of ICT facilities by teachers in the schools.

\begin{tabular}{|c|l|c|c|c|c|c|c|}
\hline $\mathrm{S} / \mathrm{N}$ & \multicolumn{1}{|c|}{ Items } & VHE & $\mathrm{HE}$ & $\mathrm{LN}$ & $\mathrm{NE}$ & $\mathrm{X}$ & Decision \\
\hline 1 & $\begin{array}{l}\text { The extent you use well equipped computer laboratory to } \\
\text { teach can be regard to be }\end{array}$ & 6 & 8 & 18 & 70 & 1.5 & No Extent \\
\hline 2 & $\begin{array}{l}\text { The extent you use these programmes, the Microsoft word, } \\
\text { Microsoft excel, page maker, adobe acrobat, power point is } \\
\text { seen to be. }\end{array}$ & 2 & 10 & 18 & 72 & 1.4 & No Extent \\
\hline 3 & $\begin{array}{l}\text { The extent you get the soft ware programme needed for } \\
\text { each topic is regarded to be. }\end{array}$ & 4 & 4 & 26 & 68 & 1.4 & No Extent \\
\hline 4 & The extent computer are accessible to you is seen to be. & 2 & 14 & 24 & 62 & 1.5 & No Extent \\
\hline 5 & $\begin{array}{l}\text { The extent power supply for use is in ICT teaching and } \\
\text { learning is regarded to be. }\end{array}$ & 4 & 4 & 24 & 66 & 1.4 & No Extent \\
\hline 6 & $\begin{array}{l}\text { The extent you use multimedia project for teaching in } \\
\text { regarded as. }\end{array}$ & 4 & 6 & 2 & 76 & 1.1 & No Extent \\
\hline
\end{tabular}


Table 2, revealed that there are ill equipped/inadequate computer laboratory, non availability and use of software programmes, non accessibility of computer, on power supply as indicated by the mean scores of $1.5,1.4,1.4,1.5,1.4$, and 1.4 respectively. There is no experienced manpower to use such software programmes, as the multimedia projector to reach students is indicated by mean score of 1.1

Table 3: The problems associated with the use of ICT facilities for teaching and learning.

\begin{tabular}{|c|l|c|c|c|c|c|c|}
\hline S/N & SA & A & D & SD & X & Decision \\
\hline 1 & The in lack of computer literacy. & 20 & 50 & 4 & 8 & 3.1 & Agreed \\
\hline 2 & There are no personal computers. & 41 & 49 & 8 & 4 & 3.2 & Agreed \\
\hline 3 & Inadequate knowledge of ICT facilities. & 45 & 39 & 14 & 4 & 3.2 & Agreed \\
\hline 4 & Lack competencies and interest required for the use of ICT facilities. & 39 & 47 & 6 & 10 & 3.1 & Agreed \\
\hline 5 & No good storage facilities. & 34 & 46 & 10 & 12 & 2.9 & Agreed \\
\hline 6 & Large class size & 42 & 44 & 8 & 8 & 3.1 & Agreed \\
\hline 7. & Lack of standby generator. & 44 & 44 & 0 & 14 & 3.1 & Agreed \\
\hline 8. & Poor funding for procurement and maintenance of computer. & 40 & 52 & 8 & 2 & 3.2 & Agreed \\
\hline 9. & Lack of internet. & 48 & 32 & 6 & 16 & 3 & Agreed \\
\hline 10. & Inadequate computer laboratory. & 44 & 36 & 8 & 14 & 3.0 & Agreed \\
\hline
\end{tabular}

Table 3, showed from the table analysis showed that all the items had the mean scores of 3.1, 3.2, 3.2, $3.12 .93 .1,3.1,3.2,3$ and 3.0 respectively, indicating acceptance that, the problems listed on the table, are applicable. These by implication are that, the sampled respondent opined that no school in the L.G.A had ICT facilities let alone, facilitating teaching and learning. Many teachers do not have personal computers, lack computer literacy and others. The mean scores of all the items were above 2.50 level of significance.

Table 4: Administrators' role to ensure quality use of ICT facilities.

\begin{tabular}{|c|c|c|c|c|c|c|c|}
\hline $\mathrm{S} / \mathrm{N}$ & & VHE & $\mathrm{HE}$ & LN & $\mathrm{NE}$ & $\mathrm{X}$ & Decision \\
\hline 1 & e must ensure that his teachers are sent on in-service training. & 64 & 26 & 6 & 4 & 3.4 & Agreed \\
\hline 2 & 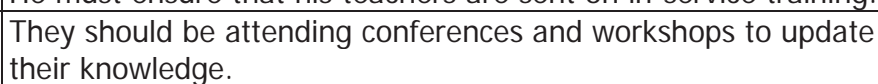 & 50 & 46 & 4 & 2 & 3.3 & Agreed \\
\hline 3 & 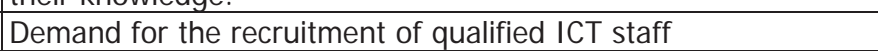 & 54 & 30 & 4 & 2 & 3.4 & \\
\hline 4 & $\begin{array}{l}\text { Mak } \\
\text { pro }\end{array}$ & 30 & 60 & 10 & 6 & 3.0 & Ia \\
\hline 5 & Ensu & 4 & 36 & 6 & 2 & 3.3 & \\
\hline 6 & $\begin{array}{l}\text { Always have a cross-straight } t \\
\text { are needs for improvement }\end{array}$ & 42 & 50 & 8 & 2 & 3.2 & \\
\hline
\end{tabular}

Table 4 results showed that administrators have great roles to play, to ensure that, there would be the availability of ICT in our schools, and the staff/manpower will be well poised in the use of the facilities.

The mean scores for each item on the questionnaire were $3.4,3.3,3.4,3.0,3.3$ and 3.2 respectively, above 2.50 cut off point for an accepted value. This therefore indicates that the respondents are in agreement that administrators have the role of ensuring quality use of ICT facilities in enhancing teaching and learning in their schools.

\section{Discussion of the Findings}

The ICT facilities in the Junior Secondary Schools (JSS) in Umuahia North are nothing to write 
home about. This is shown in table 1, that both computer, computer software programme, television sets, internet transparencies and overhead and slide projectors showed no extent of availability and use of the ICT for teaching in the schools. All the mean scores were below mean rating of 2.50 as accepted cut off point for different levels of responses which showed that the Government has not done her home work very well to meet up with the global demand of use of ICT in ensuring effective teaching and learning.

Table 2, the result showed that teachers do not access ICT facilities for teaching their students. The available computers are not connected to internet thereby depriving students and their teachers of the benefit derivable from the use of the facilities.

In table 3, teachers agreed that lack of computer literacy, lack of personal computer, inadequate knowledge of ICT facilities, lack of competencies required for the use of ICT facilities, large class size, lack of standby generator, poor funding and inadequate computer laboratory are most of the problems hindering the use of ICT facilities for teaching and learning. This is in line with (Chukwu, Ajere and Afolabi, 2003) who stated that only few teachers are computer literate in college of education in plateau state, Nigeria. Which means that, majority of people lack computer literacy, hence the use of ICT facilities to enhance teaching and learning process is hindered.

Table 4 showed the implication of this study for administrators. It showed that administrators have the role of recommending their teachers for going on in-service training. As administrators, the have the duty of supervision of work/instructions in the classrooms, ensuring funding for procurement of facilities and others. This is line with the basic principle of Thorndike's (1953:244) and Skinner law of effect (1953:1969). It stated that, by providing properly scheduled rewards, it is possible to influence individual's behaviors. For constant rewarding and reinforcement, teachers would like to learn and teach.

\section{Conclusion}

In conclusion, though ICT and ICT facilities are not available, JSS teachers in Umuahia North LGA of Abia State Nigeria do not have their own personal computers. They do not also have sufficient literacy level and skills that will enable them use the facilities for teaching and learning purposes. Also those administrators have a lot of duties for their teachers, for them to be poised, and determined to go for conferences, workshops and seminars to update their knowledge, skills, and competencies.

\section{Recommendations}

Based on the Result of eth study, the following recommendations were made.

1. The computer and internet education should be intensified at the teachers level in preparation for basic education. This is because, it will help the teachers have the skills and knowledge that will be needed for application of computer and internet for effective teaching and learning.

2. Federal Government should subsidize the provision of personal computer to teachers in JSS.

3. Teachers should knowledge of ICT facilities available in their schools as well acquire skills required for using them.

4. Serving teachers should be encourage to attend conferences, seminars and workshops to improve their competencies in the competence to use of ICT facilities for teaching

5. There must be put in place a standby generator for the use of the computer facilities since it cannot be operated without power.

6. The softwares needed for teaching should be provided.

7. The Ministry of Education and school Administrators should encourage teachers to go for in-service training on computer and internet education. 


\section{References}

Ali, A. (2000): Information Management for the Educational Sub-sector in Nigeria. Information Technology in Africa, 17, (3).

Ezeliora, B.A (2003): Problems Affecting the effective use of Nigeria. London. New World Press.

Federal Republic of Nigeria (2008), National Policy on Education.

Obagah, J (2002): Networking Challenges: The case of Nigeria. London; new World Press.

Okwor, E.A. (2003): Science and Technological Issues for Education in Information Age. Interdisciplinary Education Journal (NITEJ). 4 (1)

Skinner (1953; 1969): In Human Resource Management. Principles, Policies and practices.

Smith, I. (2000): Office of the future Management World. New York. M.C. Graw Hill. Inc. 